\title{
The Impact of Exchange Rate on Tomato Trade: Evidence from Malaysia
}

\author{
Emmy Farha Alias ${ }^{1}$, A. H. Baharom ${ }^{2}$, Illisriyani Ismail ${ }^{1} \&$ Alias Radam $^{3}$ \\ ${ }^{1}$ Institute of Agricultural and Food Policy Studies, Universiti Putra Malaysia, Serdang, Malaysia \\ 2 Taylor's Business School, Taylor's University, Subang Jaya, Malaysia \\ ${ }^{3}$ Department of Management, Faculty of Economics and Management, Universiti Putra Malaysia, Serdang, \\ Malaysia \\ Correspondence: Emmy Farha Alias, Institute of Agricultural and Food Policy Studies, Universiti Putra Malaysia, \\ 43400 UPM Serdang, Selangor, Malaysia. Tel: 60-3-8947-1073. E-mail: emmyfarha@gmail.com
}

Received: November 29, $2011 \quad$ Accepted: January 23, $2012 \quad$ Published: May 1, 2012

doi:10.5539/ass.v8n6p20

URL: http://dx.doi.org/10.5539/ass.v8n6p20

\begin{abstract}
Economists recognized that exchange rate have a significant impact on trade. In this study we employed the Autoregressive Distributed Lag (ARDL) bounds testing procedure to analyze the impact of exchange rate on tomato's export and import for Malaysia. The period of study covers 1997-2007 using quarterly data. Real Effective Exchange Rate (REER) was used rather than conventional exchange rate since this study covers the trade between Malaysia and the rest of the world. Our results indicate that both the export and import of tomatoes exhibit significant long-run relationships with REER. Causal effects in both cases are bidirectional. However, while the sign is economically correct for the relationship between REER and export, the same cannot be said for the relationship between import and REER.
\end{abstract}

Keywords: ARDL, real effective exchange rate, trade, tomato, Malaysia

\section{Introduction}

Malaysia has been experiencing trade deficits in food sector, chalking worrying figures denting her coffers whereby the deficits worsens from a whopping RM1.1billion in 1990 to RM8.5billion in 2007 (Department of Statistics, Malaysia 2008). One of the sub-sectors which contributed hugely to this trade imbalance is the sub-sector of vegetable. The deficit trade balance in this sub-sector had risen from RM241.44 million (1990) to RM1, 284.63 million (2007) (Arshad et al, 2008) with an annual average growth of 20.81\%. Even though some commodities in the vegetable sub-sector such as tomato, sweet corn, mixed vegetable and potato chip have positive trade balances and potential to grow further, the production and export share of these commodities are still quite small compared to the import of other vegetables.

Tomato trade was chosen as the subject of interest in this study due to the nature of the vegetable in being vastly involved and has been growing steadily for the last four decades. The trade also involve countries such as Australia (main source of import) and United States of America (main export destination) leading us to believe that it will have close relationship and thus will be cointegrated with the exchange rate. Malaysia is net exporter of fresh vegetables in general, however Malaysia still imports certain vegetables especially temperate ones, those that are not technically and economically viable to be produced locally. Domestic demand keeps on increasing due to a rapid increase in population and change of eating habit and life style (health conscious). The per capita consumption has increased from $27.3 \mathrm{~kg}$ in 1982 to $39.3 \mathrm{~kg}$ in 2000, and further increased to 45.8 in 2001. Due to trade liberalization, there will be an influx of vegetables, including tomatoes into Malaysia. Hence, this will have strong impact on the local tomato industry and imposed stiff competition to local growers. Tomatoes are a temperature-sensitive crop and are susceptible to frost at all stages of growth. Fruit set is also greatly influenced by temperature. These requirements favour growing areas in the temperate slopes and plains hence Cameron Highlands emerges as the most suitable and productive tomato producing region in Malaysia.

Exchange rates have long been considered as one of the prime determinants of trade in general and it is not an exception in this case. The causal relationship between the exchange rate and trade balance has been widely 
discussed and researched in previous studies and the results so far have been mixed, though in majority of the studies it is indeed found that exchange rate have profound impact on trade. Most of the researches signified that exchange rate could influence trade flow in a country. For instance, Himarios (1989) had investigated whether the devaluation of the currency will affect the real magnitude of the trade balance and his results indicated that the coefficient of the real exchange rate showed significant relationship with the trade balance. Research by Humpage (1998) showed that all the exchange rate systems and managements are associated with balance of payments. Rincon (1998) also found that exchange rate has a significant relationship on both the short run as well as the long-run behavior of Columbia's trade balance. In another notable study, Baharumshah (2001) stated that a positive long-run relationship between exchange rate and trade balance has been found in the bilateral trade between Thailand and Malaysia with one of their major trading partner - Japan. A study done by Onafowora (2003) revealed that continued depreciation for East Asian countries currencies has led to an improvement of their trade balances. On the other hand, Stucka (2004) who examined on the effects of exchange rate change towards trade balance in Croatia with six major trading partners has discovered the evidence of the J-curve effect.

Nonetheless, some researchers wonder whether exchange rate changes are able to improve or worsen trade balances as empirical evidences showed that not all countries' trade balances were affected by the changes in exchange rate. For example, Brahmasrene (2002) discovered that the real exchange rates changes have significant impact on trade balances in some countries, but not in all countries. On the other hand, Bahmani-Oskooee and Goswami (2004) investigated the impact of exchange rate towards Japan's bilateral trade flows with her nine major trading partners that include Australia, Canada, France, Germany, Italy, the Netherlands, Switzerland, UK, and the US using the ARDL approach. Their results revealed that when trade flows are measured in terms of foreign currency or reserve currency, Japan's exports are not sensitive to real exchange rate in most of the cases. This indicates that the impacts of exchange rate changes on the trade balances are either vague or ambiguous.

Changes in exchange rates will influence the agriculture sector in many ways. Exchange rate changes will impact the tomato trade through the prices of export product, the price of imported inputs, farm margins, and, thus therefore, the competitiveness of the tomato industry. These changes also affect the competitiveness of tomato exports in the international market. An increase in value of the loonie will influence the agriculture industry by making the products more expensive for foreigners unless local albeit Malaysian producers accept a lower price for their products. A decrease in value of the Malaysian currency will generally increase tomato exports and make producers more competitive, at least, in the short term or short run.

The Malaysian trade balance in general affects the value of the Malaysian Ringgit, as well. When Malaysia earns more from sales of exports than it pays for imports, it has a trade surplus. A trade surplus increases the demand for the Malaysian Ringgit and usually results in a rising Malaysian Ringgit. On the other hand, a trade deficit will lower the demand for Malaysian Ringgit and cause a decrease of the Malaysian Ringgit exchange rate.

This paper intends to examine the impact of exchange rate on the tomato's trade by decomposing the impact to the export side and import side of tomato trade in Malaysia. As we have mentioned earlier, the deficit is indeed worrying and any new approaches that could reverse the deficits or at least reduce the deficits would be breath of fresh air to the policy makers.

This paper is organized as follows: Section 2 gives a brief introduction of the methodology; Section 3 discusses the result and Section 4 concludes.

\section{Data and Methodology}

The trade data for the tomato were obtained from Global Trade Information Services, while the data for the Real Effective Exchange Rate (REER) were obtained from IMF statistics. The data are on a quarterly basis with the time span of 11 years (1997 to 2007). Both the variables are expressed in natural logs.

Model A below is used to determine the impact of exchange rate on export of tomatoes using the ARDL approach. The estimated conditional error correction (EC) is as per Equation (1) below:

$$
\Delta \ln E x_{t}=\delta_{0}+\lambda_{1} \ln E x_{t-1}+\lambda_{2} \ln E R_{t-1}+\sum_{i=1}^{\rho} \theta_{i} \ln E x_{t-i}+\sum_{i=0}^{\rho} \phi_{i} \ln E R_{t-i}+\varepsilon_{t}
$$

Whereby $\lambda_{1}$ and $\lambda_{2}$ are long-run multipliers and $\delta_{0}$ is the drift. Lagged values of $\Delta E x_{t}$ and current and lagged values of $\Delta E R_{t}$ are used to model the short-run dynamic structure. All variables in natural logarithm 
and $\rho$ is the optimal lag length.The $F$-test is conducted to test the existence of any long-run relationship. The alternative hypothesis for cointegration among variables in equation (1) is $H_{1}: \lambda_{1} \neq \lambda_{2} \neq 0$ against the null hypothesis $H_{0}: \lambda_{1}=\lambda_{2}=0$. The $F$-test has a non-standard distribution which depends on (i) the number of regressors, (ii) whether variables included in the model are $I(1)$ or $I(0)$ and (iii) whether the model consists and intercept and/or a trend. If the $F$-test statistic exceeds their respective upper critical values, we can conclude that there is enough evidence of a long-run relationship between the variables. If the F-test statistic is below the upper critical values, we failed to reject the null hypothesis of no cointegration and if it lies between the bounds, a conclusive inference cannot be made without knowing the order of integration of the underlying regressors.

If there cointegration exist, the following long-run model will be estimated:

$$
\ln E x_{t}=\beta_{1}+\delta \ln E x_{t-1}+\phi \ln E R_{t-1}+v_{t}
$$

The orders of the lags in the ARDL model are selected by either the Schwarz Bayesian criterion (SBC) or the Akaike information criterion (AIC), before the selected model is estimated by ordinary least squares (OLS).

The ARDL specification of the short-run dynamics can be derived by constructing an error correction model (ECM) of the following form:

$$
\Delta \ln E x_{t}=\alpha_{1}+\sum_{i=1}^{\rho} \lambda_{2 i} \Delta \ln E x_{t-i}+\sum_{i=0}^{\rho} \varpi_{2 i} \Delta \ln E R_{t-i}+\psi E C M_{t-1}+\xi_{t}
$$

Whereby $\mathrm{ECM}_{\mathrm{t}-1}$ is the error correction term, defined as:

$$
E C M_{t}=\ln E x_{t}-\beta_{1}-\delta \ln E x_{t-1}-\phi \ln E R_{t-1}
$$

All coefficients of the short-run equation are coefficients relating to the short-run dynamics of the model's convergence to equilibrium and $\psi$ represent the speed of adjustment.

Subsequently model B is used to determine the impact of exchange rate on import of tomatoes, and the estimated conditional error correction (EC) is as Equation (5) below:

$$
\Delta \ln \operatorname{Im}_{t}=\delta_{0}+\lambda_{1} \ln \operatorname{Im} \ln _{t-1}+\lambda_{2} \ln E R_{t-1}+\sum_{i=1}^{\rho} \theta_{i} \ln \operatorname{Im} \ln _{t-i}+\sum_{i=0}^{\rho} \phi_{i} \ln E R_{t-i}+\varepsilon_{t}
$$

Whereby $\lambda_{1}$ and $\lambda_{2}$ are long-run multipliers and $\delta_{0}$ is the drift. Lagged values of $\Delta \mathrm{Im}_{t}$ and current and lagged values of $\triangle E R_{t}$ are used to model the short-run dynamic structure and the $F$-test is conducted to test the existing of the long-run relationship whereby the alternative hypothesis for a cointegration among variables in equation (5) is $H_{1}: \lambda_{1} \neq \lambda_{2} \neq 0$ against the null hypothesis and it will be followed by the estimation of the long run coefficients via the model below:

$$
\ln \operatorname{Im}{ }_{t}=\beta_{1}+\delta \ln \operatorname{Im} t_{t-1}+\phi \ln E R_{t-1}+v_{t}
$$

The ARDL specification of the short-run dynamics can be derived by constructing an error correction model (ECM) of the following form:

$$
\Delta \ln \operatorname{Im}{ }_{t}=\alpha_{1}+\sum_{i=1}^{\rho} \lambda_{2 i} \Delta \ln \operatorname{Im}{ }_{t-i}+\sum_{i=0}^{\rho} \sigma_{2 i} \Delta \ln E R_{t-i}+\psi E C M_{t-1}+\xi_{t}
$$

Whereby $\mathrm{ECM}_{\mathrm{t}-1}$ is the error correction term, defined as:

$$
E_{t}=\ln \operatorname{Im}{ }_{t}-\beta_{1}-\delta \ln \operatorname{Im}{ }_{t-1}-\phi \ln E R_{t-1}
$$

All coefficients of the short-run equation are coefficients relating to the short-run dynamics of the model's convergence to equilibrium and $\psi$ represent the speed of adjustment.

As for the impact of both export and import of tomatoes on the exchange rate, the role of the variables will be 
reversed, and exchange rate will be used as the dependent variable while the export and import will be used as explanatory variables as per Equation (9) and Equation (10) below;

$$
\begin{aligned}
& \Delta \ln E R_{t}=\delta_{0}+\lambda_{1} \ln E R_{t-1}+\lambda_{2} \ln E x_{t-1}+\sum_{i=1}^{\rho} \theta_{i} \ln E R_{t-i}+\sum_{i=0}^{\rho} \phi_{i} \ln E x_{t-i}+\varepsilon_{t} \\
& \Delta \ln E R_{t}=\delta_{0}+\lambda_{1} \ln E R_{t-1}+\lambda_{2} \ln \operatorname{Im}{ }_{t-1}+\sum_{i=1}^{\rho} \theta_{i} \ln E R_{t-i}+\sum_{i=0}^{\rho} \phi_{i} \ln \operatorname{Im} t_{t-i}+\varepsilon_{t}
\end{aligned}
$$

While the long run coefficients will be estimated via Equation (11) and (12) below:

$$
\begin{aligned}
& \ln E R_{t}=\beta_{1}+\delta \ln E R_{t-1}+\phi \ln E x_{t-1}+v_{t} \\
& \ln E R_{t}=\beta_{1}+\delta \ln E R_{t-1}+\phi \ln \operatorname{lm} t_{t-1}+v_{t}
\end{aligned}
$$

On the other hand, dynamic relations will be estimated as per error correction model (ECM) Equation (13) and Equation (14) below:

$$
\begin{gathered}
\Delta \ln E R_{t}=\alpha_{1}+\sum_{i=1}^{\rho} \lambda_{2 i} \Delta \ln E R_{t-i}+\sum_{i=0}^{\rho} \sigma_{2 i} \Delta \ln E x_{t-i}+\psi E C M_{t-1}+\xi_{t} \\
\Delta \ln E R_{t}=\alpha_{1}+\sum_{i=1}^{\rho} \lambda_{2 i} \Delta \ln E R_{t-i}+\sum_{i=0}^{\rho} \sigma_{2 i} \Delta \ln \operatorname{lm}{ }_{t-i}+\psi E C M_{t-1}+\xi_{t}
\end{gathered}
$$

All coefficients of the short-run equation are coefficients relating to the short-run dynamics of the model's convergence to equilibrium and $\psi$ represent the speed of adjustment whereby $\mathrm{ECM}_{\mathrm{t}-1}$ is the error correction term, defined as:

$$
E C M_{t}=\ln E R_{t}-\beta_{1}-\delta \ln E R_{t-1}-\phi \ln E x_{t-1}
$$

and,

$$
E C M_{t}=\ln E R_{t}-\beta_{1}-\delta \ln E R_{t-1}-\phi \ln \operatorname{Im}{ }_{t-1}
$$

\section{Empirical Results}

Table 1 reports the results of Augmented Dickey-Fuller (ADF) unit root test that describes the stationary properties of all variables (export, import and real effective exchange rate) in Malaysia. Schwartz Information Criterion (SIC) is used to select the optimal truncation lag length to ensure the errors are white noise. The result clearly shows that the null hypothesis of unit root test for all variables fail to be rejected in the level form but only appear stationary in the first different. In other words, all variables are said to be integrated of order one, which is I(1).

Table 1. Results of ADF Unit Root Test

\begin{tabular}{lcc}
\hline Variables & $\begin{array}{c}\text { Level } \\
\text { (Trend and Intercept) }\end{array}$ & $\begin{array}{c}\text { First Difference } \\
\text { (Trend and Intercept) }\end{array}$ \\
\hline $\ln$ Ex & $-0.4059(7)$ & $-4.5764^{* * *}(6)$ \\
$\ln$ Im & $-2.7802(3)$ & $-10.5230^{* * *}(2)$ \\
$\ln$ ER & $-2.9582(0)$ & $-4.3919 * * *(0)$ \\
\hline
\end{tabular}

Note: Superscript $* * *$ denotes significant at $1 \%$ level.

The calculated $F$-test statistics for cointegration are reported in Table 2 below. There are cointegrating relationship between real effective exchange rate (ER), and both import (Im) and export (Ex) of tomatoes.

Table 2. Cointegration Test

\begin{tabular}{l}
\hline F-test $)$ \\
\hline $\mathrm{F}(\mathrm{ER} \mid \mathrm{Im})=4.3283^{*}$ \\
$\mathrm{~F}(\mathrm{ER} \mid \mathrm{Ex})=4.8552^{* *}$
\end{tabular}

Note: The $10 \%$ critical values for $\overline{\mathrm{I}(0)}$ and $\mathrm{I}(1)$ are 3.190 and 3.730 . The corresponding $5 \%$ and $1 \%$ critical values are 3.877, 4.460, and 5.607 and 6.193 respectively. The critical values are obtained from Narayan (2005). 
Table 3 shows the result of long-run elasticities. The signs of the coefficients generally are in tandem with trade theories, whereby increment in the import in the long run will cause our currency to depreciate while increment in export of tomatoes will cause our currency to appreciate, on the other hand depreciation in our currencies will boost the export of tomatoes. However, while it is a well known factor that depreciation in our currencies should deter imports, the results are surprisingly on the contrary. As for the significance of these variables, only import of tomatoes seems to affect exchange rate in the long run significantly.

Table 3. Long-run Elasticities

\begin{tabular}{lccc}
\hline Dependent Variables & \multicolumn{3}{c}{ Independent Variables } \\
& $\ln$ ER & $\ln$ Im & $\ln$ Ex \\
\hline $\ln$ Im & -0.3590 & & \\
& $(-0.2747)$ & & \\
$\ln$ Ex & -1.3287 & & \\
& $(-0.4712)$ & $3.9774^{* * *}$ & -0.0688 \\
$\ln$ ER & & $(9.5321)$ & $(-1.2952)$ \\
\end{tabular}

Notes: Superscripts $* * *$ denotes significance at $1 \%$ levels respectively. t-stats in parentheses.

The results of the short run elasticities are presented in Table 4. Looking at the In the ECM, all coefficients are statistically significant at different level. The results show that the error correction term $\left(\mathrm{ECM}_{\mathrm{t}-1}\right)$ is negative, indicating that the feedback mechanism is very effective in Malaysia and it seems to suggest bidirectional Granger causality between Tomato trade and Exchange rate.

$$
\begin{aligned}
& \mathrm{Im} \leftrightarrow E R \\
& E x \leftrightarrow E R
\end{aligned}
$$

\begin{tabular}{|c|c|c|c|c|}
\hline \multirow{2}{*}{$\begin{array}{l}\text { Dependent } \\
\text { Variables }\end{array}$} & \multicolumn{4}{|c|}{ Independent Variables } \\
\hline & $\Delta \ln \mathrm{ER}$ & $\Delta \ln \operatorname{Im}$ & $\Delta \ln E x$ & $\mathrm{ECM}_{\mathrm{t}-1}$ \\
\hline \multirow[t]{2}{*}{$\Delta \ln \operatorname{Im}$} & -0.3590 & & & $-0.9998 * * *$ \\
\hline & $(-0.2747)$ & & & $(3.800)$ \\
\hline \multirow[t]{2}{*}{$\Delta \ln \mathrm{Ex}$} & 1.8508 & & & $-0.1872 *$ \\
\hline & $(1.6463)$ & & & $(-1.7045)$ \\
\hline \multirow[t]{2}{*}{$\Delta \ln \mathrm{ER}$} & & 0.0003 & & $-0.2221 * * *$ \\
\hline & & $(0.0357)$ & & $(-4.0804)$ \\
\hline \multirow[t]{2}{*}{$\Delta \ln \mathrm{ER}$} & & & 0.0176 & $-0.2548 * * *$ \\
\hline & & & $(0.8983)$ & $(-3.9820)$ \\
\hline
\end{tabular}

Table 4. Short-run Elasticities

Notes: Superscripts $*, * *$ and $* * *$ denotes significance at $10 \%, 5 \%$ and $1 \%$ levels respectively. $\mathrm{t}$-stats in parentheses.

\section{Conclusion}

We conducted a bivariate analysis between export and import of the vegetable produce namely tomato, and exchange rate, to be specific, real effective exchange rate. We applied the autoregressive distributed lag (ARDL) bounds testing procedure to investigate the dynamic and long-run relationship between trade variable (import and export of tomato) and exchange rate using quarterly data for the period 1997 to 2007.

The findings suggest that trade variables and exchange rate are non-stationary variables and achieved stationarity at first different level. The cointegration analysis using ARDL bounds testing procedure indicate that trade variables are cointegrated with exchange rate. The presence of cointegration between these variables tends to suggest that they are bound together by common trends or long-run relationship. About the causal effect, bidirectional causality is detected between variables.

For the policy implication, government should encourage producers to export more tomatoes either in fresh or 
processed food to stabilize our exchange rate and also achieved surplus trade balance in this commodity. The strong and stable exchange rate policy should be implemented because this policy has relationship with the tomato's trade.

\section{References}

Arshad, FM, Shuib, A, Radam, A, Abdullah, AM, Azali M, Latif, IA, Rahim, KA, Noh, KM, Ismail, MM, Yacob, MR, \& Mohamed, Z. (2008). Penilaian Pelan Tindakan Imbangan Perdagangan Sektor Makanan. research report submitted to Ministry of Agriculture and Agro-based Industry Malaysia, 748.

Baharumshah, AZ. (2001). The effect of exchange rate on bilateral trade balance: new evidence from Malaysia and Thailand. Asian Economic Journal, 15(3), 291-312. http://dx.doi.org/10.1111/1467-8381.00135

Bahmani-Oskooee, M., \& Goswami, GG. (2004). Exchange rate sensitivity of Japan's bilateral trade flows. Japan and the World Economy, 16, 1-15. http://dx.doi.org/10.1016/S0922-1425(03)00016-1

Bahmani-Oskooee, Mohsen, \& Kovyryalova, Marina. (2008). Impact of exchange rate uncertainty on trade flows: evidence from commodity trade between the United States and the United Kingdom. The World Economy, 31(8), 1097-1128. http://dx.doi.org/10.1111/j.1467-9701.2008.01116.x

Brahmasrene, T. (2002). Exploring real exchange rate effects on trade balances in Thailand. Managerial Finance, 28(11), 16-18. http://dx.doi.org/10.1108/03074350210768130

Department of Statistics Malaysia. (2007). Food Trade Statistics.

Duncan, A. (2008). Currency devaluation and trade performance: a case of Jamaica. Journal of International Finance and Economics, 8(4).

Himarios, D. (1989). Do devaluations improve the trade balance? The evidence revisited. Economic Inquiry, 27(1), 143-168. http://dx.doi.org/10.1111/j.1465-7295.1989.tb01169.x

Humpage, O. (1998). A Hitchhiker's guide to understanding exchange rates. FRB Cleveland Economic Commentary Series, Issue Jan 1.

Narayan, P. K. (2005). The Saving and Investment Nexus for China: Evidence from Cointegration Tests. Applied Economics, 37, 1979-1990. http://dx.doi.org/10.1080/00036840500278103

Onafowora, O. (2003). Exchange rate and trade balance in East Asia: Is there a J-curve. Economics Bulletin, $5(18), 1-13$.

Pesaran, MH, Shin, Y., \& Smith, R. (2001). Bounds Testing Approaches to the Analysis of Level Relationship. Journal of Applied Econometrics, 16, 289-326. http://dx.doi.org/10.1002/jae.616

Puah, CH, Yong, SW, Mansor, SA, \& Lau, E. (2008). Exchange rate and trade balance nexus in Asean-5. Labuan Bulletin of International Business and Finance, 6, 19-37.

Rincon, CH. (1998). Testing the short and long-run exchange rate effects on trade balance: The case of Colombia. Working Paper Series, No. 120. Banco de la Republica de Colombia.

Stucka, T. (2003). The impact of exchange rate changes on the trade balance in Croatia. Working Paper Series. Zagreb: Croatian National Bank.

Stucka, T. (2004). The effects of exchange rate change on the trade balance in Croatia. IMF Working Paper, No. WP/04/65. Washington, D.C.: International Monetary Fund. 